\title{
Rola terenów nadbrzeżnych i parków kieszonkowych w ksztaltowaniu środowiska mieszkaniowego na przykładzie osiedla Nordhavnen w Kopenhadze
}

\section{Role of waterfront areas and pocket parks in shaping of housing environment on the example of the Nordhavnen Housing Estate in Copenhagen}

\section{Streszczenie}

Celem artykułu jest przedstawienie będącego obecnie w trakcie realizacji, jednego z największych projektów rozbudowy miasta jaki ma miejsce w Skandynawii, znanego pod nazwą Nordhavnen. Artykuł przybliży podstawowe założenia ideow ce im praktyczne narzedzia urbanistyczne. Artykut przyjrzy sie jak w praktyce wyglada realizacje założé koncepcyinych ze szczególnym uwzglednieniem terenów zielonych - parków kieszonkowych i tzw. stref buforowych - oraz wodnych - terenó

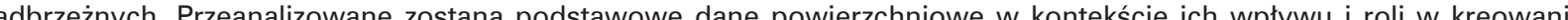
wyżej wymienionych przestrzeni.

\section{Abstract}

The goal of the article is the presentation of one of the largest city expansion projects that are currently being executed in

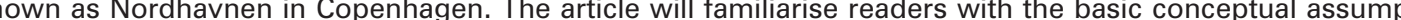
tions and design strategies that were adopted by the authors of its design, as well as the practical urban planning tools that correspond to them. The article will also explore how the implementation of the conceptual assumptions looks like in practice, with a specific emphasis on green areas-pocket parks and so-called edge zones-and those close to water-waerfronts. Basic data concerning various types of surface area in the context of their impact and role in creating the aforementioned spaces were analysed.

Stowa kluczowe: tereny nadbrzeżne, parki kieszonkowe, edge zone (strefa buforow
ty (dostepnnośc piesza)
Keywords: waterfronts, pocket parks, edge zone, sustainable mobility, walkability

\section{Wstęp}

Nordhavnen położony jest w odległości około $4 \mathrm{~km}$ na pơłnocny-wschód od centrum Kopenhagi. Swój obecny ksztalt zawdzięcza ciąglemu procesowi odzyskiwania terenów nadbrzeznych jaki miał miejsce na przestrzeni 150 lat, a rozpoczęty mniej więcej w połowie XIX wieku'. Do lat 70-tych XX wieku - kiedy to zaznacza się stopniowe zmniejszanie jego roli - funkcjonował jako prężnie działa-

\section{Introduction}

Nordhavnen is located to the north-east of the centre of Copenhagen, at a distance of around $4 \mathrm{~km}$ away. It owes its current shape to the continuous process of reclaiming waterfront areas that has taken place over the past 150 years, and which began around the middle of the nineteenth century'. Up to the 1970'swhen a marked decline in its role was taking place- jący port dla przypływających statkow przyczyniając się zachowane budynki datuja się na poczatek XX wieku. Dzisiaj Nordhavnen stanowi część dystryktu Østerbro, od którego jest oddzielony drogą Kalkbrænderihavnsgade oraz linią kolejow

W zakresie transportu publicznego obszar ten obstu giwany jest przez wyżej wymieniona kolej i okresowo przez linie autobusowa. Ze wzgledu na priorytetowy charakter dzienicy planowane sa wielkie iniostycie in frastrukturalne: nowa linia metra oraz obwodnica drogowa biegnąca w tunelu³

2. Konkurs

Potrzeba organizacji konkursu obejmującego swoim zakres tak znaczny obszar terenu wynikała ze spodziewanego w prognozach demograficznych dla Kopenhagi dynamicznego wzrostu populacji w nadchodzących latach. Opracowane w tamtym czasie prognozy zakładały, że do 2025 roku liczba nowych mieszkañców miasta zwiększy się o około $100000^{4}$. Dla stolicy Danii - liczącej 540000 mieszkańców - oznaczalo to koniecznosc znalezienia i to w stosunkowo krótkim czasie, miejsca dla 20-to\% przyrostu ludności miasta. Nordhavnen - jeden z głównych obszarów przyszlych dziatan inwestycyjnych - ze względu na swoje położenie, wielkość, oraz charakter stał się wręcz naturalnym wyborem

Do ogłoszonego w maju 2008 roku międzynarodowego konkursu nadesłanych zostało 180 prac, spośród których jury wybrało trzy najlepsze zakwalifikowane do drugiego etapu. Wybranym trzem biurom projektowym - 70N Arkitektur, Dahl \& Uhre Arkitekter; Cobe, Sleth Rambøll; Polyform dano dodatkowe dwa miesiące na przedstawienie zaktualizowanych koncepcii, uwzgledniajacych zalecenia jury konkursowego. Ostatecznie za najepsza koncepcje uznano projekt zatytutowany Nordholmene - Urban Delta"7 opracowany przez konsorcium

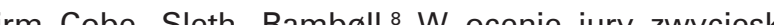
propozyce dzielnicy o róznodnej spotecrie chan

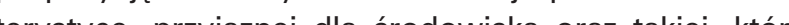
w W najlepszy mozilwy sposób wykorzysta i podkresli poKo Kontakt z wodą oraz kulturowe dzledzictwo stanowily kndament przyestych rozwizan. Dod in koncepcji udało się uzyskac zwartą i intensywną struk turę, przy jednoczesnym utrzymaniu charak enystyczne dla Kopenhagi sylwety miasta, której obraz tworzą 6-cio kondygnacyjne budynki - jako baza - akcentowana wy sokimi dominantami.

3. Podstawowe założenia projektowe

Podstawowe założenia projektowe oparte zostały na 6 hasłach / wytycznych, sformułowanych już na wczesnych etapie przedprojektowym $w$ ramach spotkan warsztatowych z mieszkańcami ${ }^{9}$. Jednym z nich było it functioned as a dynamically operating port for incountry's economic development. The oldest surviving buildings are dated to the start of the twentiet century.

Today Nordhavnen constitutes a part of the Østerbro district, from which it is separated by Kalkbræ derihavnsgade Street and a rallway line constituting a part of regional and local routes?

In terms of public transport, the area is serviced by the abovementioned railroad route and, periodically, by a bus line. Due to the priority status of the district, large-scale infrastructural projects are being planned: a metropoltan railway line and a bypass placed in a tunnel ${ }^{3}$.

\section{The competition}

The need to organise a competition that would cover this large area had been the result of dynamic population growth projected in demographic forecasts for Copenhagen for the coming years. Prognoses formulated at the time assumed that by 2025 the number of new residents of the city would increase by around 100000 . This meant that the capital of Denmark - with a population of 540000 residentswold have to find room for a $20 \%$ increase in the city's population and in a relatively short time as we Nopdher ap a developme operations .

national which its jery among which ins juy aulifed the three be thee seloctor cosite

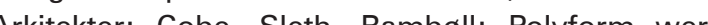
const apdated

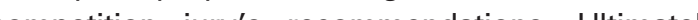
the proposal entitled Nordholmene - Urban Delta" the jury's opinion, the winning entry the best corresponded to the expected district with socilly diverse characteristics, environmentally friendly, which utilise and highlight local assets and the historica identity of Nordhavnen in the best possible manne Contact with water and the district's cultural heritage constituted a foundation for the adopted solutions. In addition the authors of the proposal managed to produce a compact and dense structure, while simuttaneously maintaining Copenhagen's distinct skyline, whose image is composed of six-storey buildingsas a basis-and is accentuated by tall landmarks.

3. Basic design assumptions

The proposal's basic design assumptions were based on six mottoes / guidelines, which had been formulated already during the early pre-design stage as a part of workshop meetings with residents ${ }^{9}$. One of them was the expectation to create a district for 


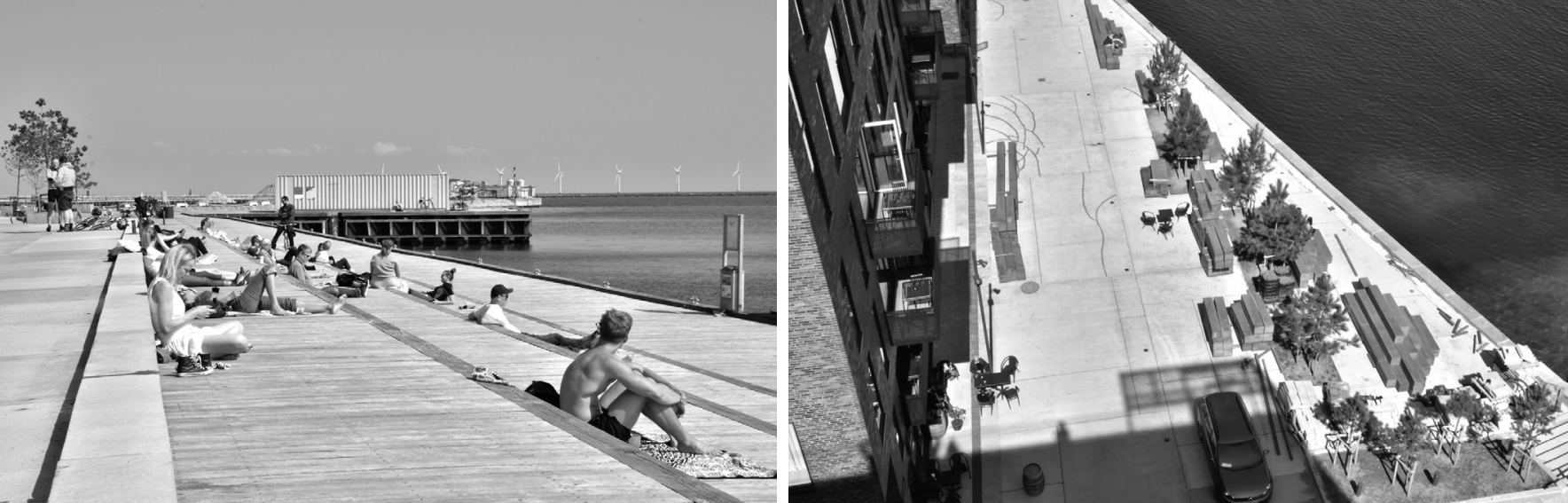

II. 1. Widok w kierunku wschodnim na nadbrzeże Sandkaj. Żródto: materiały własne / Eastwards view of Sandkaj wharf. Image source: original work 11. 2. Widok z dachu garaziu wolnostojacego $w$ dót $w$ kierunku nadbrzeia i in park kieszonkowy przy kanale Redmole. Żródto: materiaty wasne
View from the roof fof a detached garage building, downwwards in the direction of the waterffront and a pocket park near the Redmolen canal. Image
source: original work

oczekiwanie stworzenia dzielnicy dla każdego, bowiem zrównoważone miasto postrzegane jest przez Duńczy-
ków nie tylko przez pryzmat ochrony środowiska, lecz ków nie tylko przez pryzmat ochrony środowiska, lecz
również poprzez jego zdolność do kreowania różnorodrównież poprzez jego zdolność do kreowania rö̇no
nego społecznie środowiska mieszkaniowego ${ }^{0}$.

Ostatecznie sformułowano 5 haseł leżących u podstawy całego założenia, które przedstawiają się następująco miasto kompaktowe, zrównoważone, z bliskim kontaktem do wody, aktywne oraz charakteryzujące się bogactwem pozytywnych kontrastów

Powyższe hasła zostały zinterpretowane $w$ konkretne działania projektowe, które nadały załozeniu niezwykle indywidualny, wyrazisty charakter. Głównym elementem kompozycyjnym jest drobna siatka urbanistyczna pozwalająca w przyszłości na elastyczne modyfikowanie przyjętych założeń bez obawy zniekształcenia struktury kompozycyjnej dzielnicy. Dzięki niej zrealizowano również koncepcje zwiększonej pieszej dostępności między blokami zabudowy. Czytelności układu siatki urbnistycznej nie zaburza nawet rezygnacja z prostych osi kompozycyjnych..$^{12}$

Całość obszaru została podzielona na mniejsze wyspy

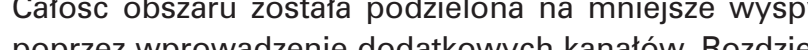

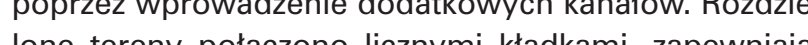
(icznyi kackami, zapewniajacymi splawnosc dla miejszych jednostek pływających. Przedzente kanalo jako przestzenir cyjne przysztych mieszkantców. Każdy z uksztaltowanych $w$ ten sposób półwyspów, wysp i wysepek ma swó whasny niepowarzalny charakter i tożsamośc: Arhusgade, Sundmolen, Redmolen, Levantkaj. Różnorodnośc została wydobyta dzięki strategii ochrony, twórczej adaptacji i rozbudowie najbardziej wartościowej historycznie tkanki urbanistycznej, podkreślając tym samym związek z portowym i handlowym dziedzictwem dzielnicy. ${ }^{13}$ $\mathrm{Na}$ siatkę urbanistyczną nałożono następnie zielon pętlę rowerową stanowiącą również rdzeń komunikacji autobusowej. Jest to rodzaj szybkiej ścieżki rowerowej ponad, którą na wiadukcie będzie przebiegała linia metra. ${ }^{14}$ Zrównoważone formy komunikacji w Nordhavnen mają pierwszeństwo nad ruchem samochodowym, dla- everybody, as Danes view the sustainable city not only through the prism of environmental protection but also through its capacity to create a socially diUltimaty, five mottoes had beer

政 as the foundation of the entire layout, which are as

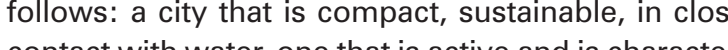
ised by a wealth of positive contrasts ${ }^{11}$

The mottoes presented above had been interpreted The mottoes pres ento specific design meen interpreted gave the layout an extraordinarily individul, expressive character. The main compositional element is a fine urban grid that enables the flexible modification of adopted assumptions without fear of deforming the district's compositional structure. It made possible to implement the concept of inc. It made ability between urban blocks. Even the aband walkof long straight compositional axes did not disrupt the readability of the urban grid

The entire area was divided into smaller islands The entire area was divided into smaller islands
through the introduction of additional canals. The divided areas were connected using numerous footbridges, ensuring navigability for smaller boats. The division using canals increased accessibility to water, understood as a space meant to satisfy the biophilic and recreational needs of future residents. Each of the peninsulas, islands and islets created in this manner was given its own unique character and identity: Arhusgade, Sundmolen, Redmolen, Levantkaj. Diversity was highlighted through the use of a strategy of protection, creative adaptation and expansion addressed to the most historically valuable buildings, thus highlighting the link with the port and commerce-related heritage of the district ${ }^{1}$

A green bicycle loop was later superimposed upon the urban grid, also forming a core for bus-based circulation. It is a type of rapid-transit bicycle route, above which there will be a metropolitan railway line, placed on a viaduct ${ }^{14}$. Sustainable forms of circulation in Nordhavnen take precedence over vehicular traffic, which is why they were given-in contrast to cars-the fastest and most rational routes ${ }^{15}$. The goal tego ich przebieg - inaczej niż samochodów - odbywa Celem takiej strategii jest nie tylko utrzymanie na obecnym poziomie procentowym udziału podróży rowerem w codziennym podziale zadań transportowych, ale przyczynienie się do jego zwiększenia z obecnych $36 \%$ do $50 \%$, niezależnie od spodziewanego $20 \%$ zwieksszenia populacji miasta w najbliższych latach.

$W$ ramach planu dla dzielnicy Arhusgade zieleń wystepuje gtównie w formie wewnetrznych parków kieszonkuje glón" powstatych w miejscu przesunieć w bleszonzabudowy. Parki te ch miejtery przesie niewielkimi rozmo wy, z dala od z Wy, z dala od zgielku glów wewh cingow pleszych, będ mogly funkcjonowac Zabres teri ím ziel

zielonych zwiększa się im dalej na północ, gdzie na nadmorskim krańcu przejdzie w obszerne połacie parkowe. Jak należy przypuszczać, realizowan

Nim jednak to nastapi $w$ dzielnicy Sundmolen zaprojektowany został już teraz ${ }^{17}$ park linearny o największych jak do tej pory rozmiarach. Przebiegał będzie nieprzerwanie, na całej długości od obu końców terenu. Największy z parkow zaprojektowano po południowej stronie w pasie terenu na wysokosci basenu portowego Nordhavn Bassin między obszarami Arhusgade i Marmormolen. ${ }^{18}$ Cechą charakterystyczną projektowanego zespołu jest 5 minutowa dostępność, która oznacza, że dystans z mie sca zamieszkania do obiektów użyteczności publicznej usług i handlu oraz przystanków komunikacji zbiorowe nie przekroczy 400 metrów. Elementami wspierającymi to założenie, a jednocześnie niezbẹdnymi w przypadku kreowania dzielnic dostepnych dla pieszych (walkable neighbourhood) sa między innymi duża intensywnośc zabudowy oraz różnorodność funkcii w budynkach Duż intensywność dla Kopenhagi odpowiada wskaźnikowi na poziomie 1.8, charakterystycznym da nazkniciej zaludnionych obszarów w mieście. Sama gejgeść ciej zalowy nie die jednak zadowajacych rezultośc jeśli zabudowa, przedze jo fizyczen nie odpou szeroko Gehl w książce Cities for People..$^{20} \mathrm{~W}$ przypadku

1. 3. Park kieszonkowy. Widok w kierunku zachodnim. Żrodio: materialy wiasne / Pocket park, Westward view. Image source: original work II. 4. Park kieszonkowy $w$ budowie. Widok $w$ kierunku wschodnim $w$ tle po lewej garaż wolnostojacy P-hus Lüders. Źródto: materiaty whasne /
Pocket park under construction. Eastwards view, with the P-hus Lüders detached garage building seen on the left side of the background. Image

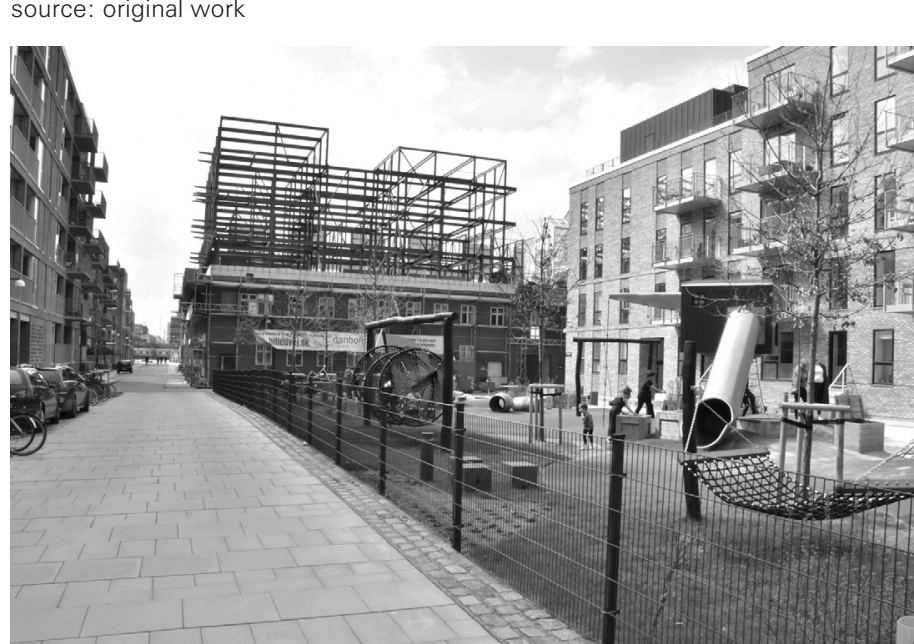

of this strategy is not only maintaining the current percentage share of bicycle traffic in the everyday division of transport tasks, but leading to its increase from the current $36 \%$ to $50 \%$, regardless of the expected $20 \%$

The plans for the Arhusgade district feature greenery primarily in the form of internal "pocket parks" created in place of shifts in urban blocks. These parks are characterised by their small size. Thanks to being located inside the development structure, far from the noise of the main pedestrian route sequences, they will be able to function as calmer places of seclusio and relaxation

The scope of green areas increases further north stage of the development project.

However, a linear park has already $y^{17}$ been designed in the Sundmolen district, the largest one to be built so far. It will form a continuous link between both ends of the area along its entire length. The largest of the parks was designed on the southern side, on a belt of land at the height of the Nordhavn Bassin port basin Ormormolen

One distinct quality of the complex that is being designed is its five-minute accessibility, which mean that the distance from a place of residence to public bullings, services, shops and public transit stops this objective, and which are simults that support hary for the, astablishment of walkable neigheceshoods, are, among other things, high urban density and functionat variety within buldings themselves'. To Copenhagen, high density is considered to be present at a level of 1.8 , which is characteristic for the most densely populated areas in the city. Urbar pensty itself, however, does not provide satisfactory results unless buildings, spatial relationships and psychophysical conditions do not conform to the human scale, which was discussed at length by Geh in his book Cities for People ${ }^{20}$. In the case of Nordin his book Ciles for $P$ o few exceptions that consttute spatial landmarks-average building height21 is maintained at a level of around six store

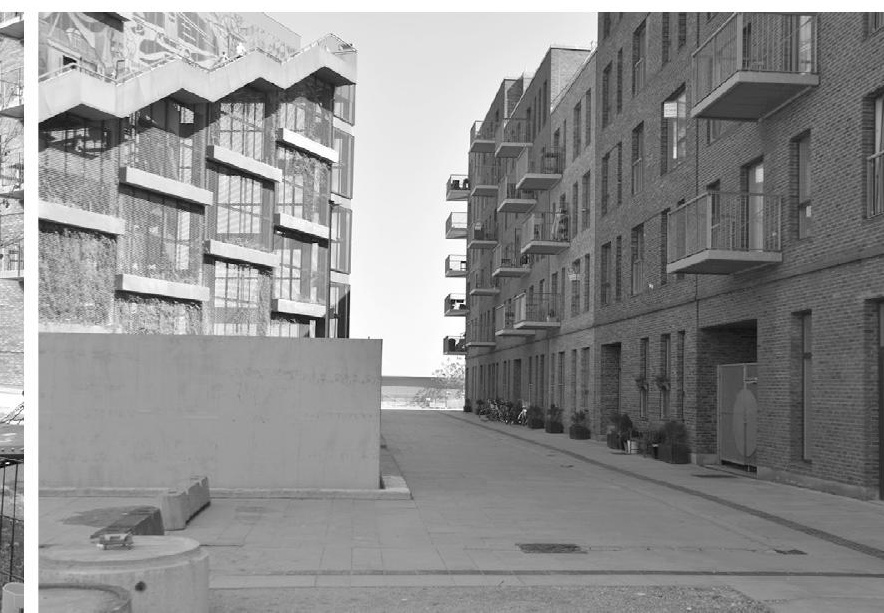
where at its seaside tip it will turn into an expansive park. It is to be assumed that it will be built as the fina 
reny zielone do niewielkich skwerów, dając tym samym funkcjonalnie zabudowie. Te dwa narzedzie projektowegestość i różnorodność funkcji - należą do jednych z najważniejszych przy zmniejszaniu potrzeb transportowych mieszkańców, prowadząc w konsekwencji do skuteczneo kreowania życia miedzy budynkami oraz zrównowajonego środowiska mieszkaniowego, co jak sie wydaje ma szansę stać się udziałem Nordhavnen.

\section{PRZYPISY}

Rozwój tego obszaru wynikat nie tylko ze stale zmieniajacych sie wiel-
kości statków i wynikajacych stad sposobów rozzadunku towaru, ale punież by indukowany rosnącą konkurencja ze strony innych ośrodków

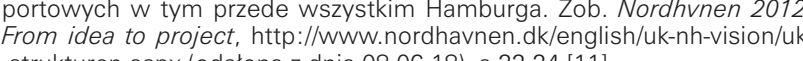
strukturen.aspx (odstona z dnia 08.06 .18$)$, s.22-24 [11]
2 Na pótnocnym-wschodzie znajuluja się dwa porty Kalkbrenderihavnen i Svanemollehavnen, Z Których jeden wykorzystywany jest na cele handlo-
we, a drugi stanowi marine. Na pótnocy potoziony jest terminal konteneowy oraz obszar o mieszanym sposobie użytkowania. Czéść wschodni
stanowi wejście do portu, który wchodzi w glab ladu, docierajac do serc Kopenhagi. Na potudniu znajduje sie dzielnica Sondre Frihavn, znana rów-
nież jako port potudniowy, która jest mieszanką funkcji mieszkaniowych niez jako port po
i ustugowych.
${ }_{3}$ Niestety sp

${ }_{3}^{3}$ Niestety spoteczny odbiór tych inwestycii, w mieście tak dalece uwraż

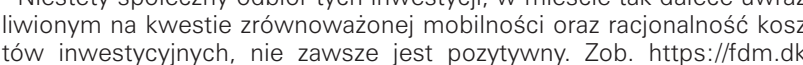
node/2107 i https://ing.dk/artikel//nordhavnstunnel-rammes-af-ekstrare

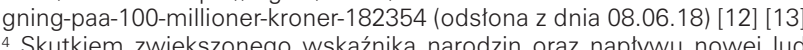
ności
sNordhvnen 2012..., ibidem s.4

Niemalize wszystkie tereny poprzemystowe w Kopenhadze zlokalizowa
ne $w$ strefach prybbrzeżnych przechodza obecnie przekszztatcenia na wie lofunkcyine zespoly urbanistyczne.
, http://www.nordhavnen.dk/english/uk-nh-vision/uk-nh-competition.aspx (odstona a dnia 08.06.18) [14] 8 Biuro Polyform zostato zaproszone do uczestnictwa $w$ dalszych pracach
projektowych nad planem zagospodarowania terenu $w$ formie zewnetrtznego konsultanta Nordhnuen 2012.., ibidem, s.10 oraz http://urbantransform.eu/wp-con-
ent/uploads/sites/2/2015/07/D4.2-Copenhagen.pdf, s.9 (odstona z dnia tent/uploads/sites/2/2015/07/D4.2-Copenhagen.pdf, s.9 (odstona z dnia
08.06 .18 ) (15]

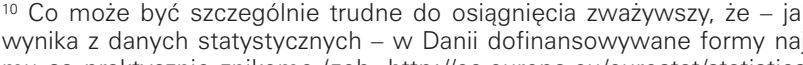
explained/index. php? ?title=File: Distribution of pop nulation by tenure

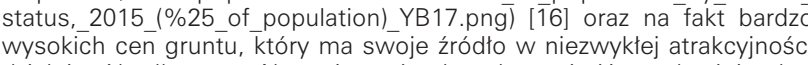

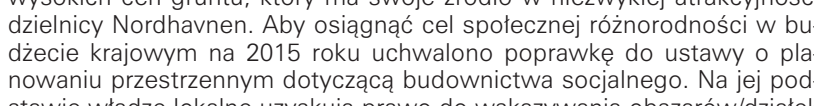

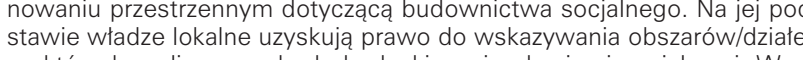
nak których realizowane beda budynki z mieszkaniami socjalnymi. W ra-
mach tych dziatek w budynkach do $25 \%$ mieszkañ przeznaczana bẹdzie

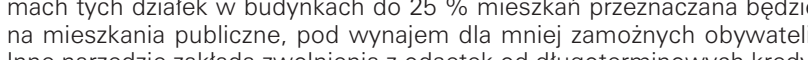

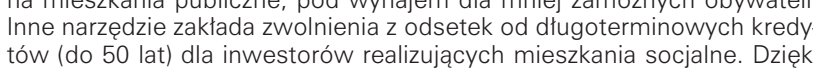

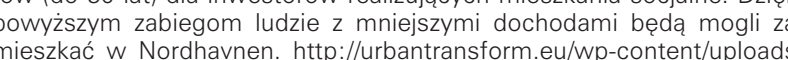
sites/2/2015/07/D4.2-Copenhagen.pdf s.20 (odstona z dnia 08.06.18) [15] nstycznych Budynki niskie równoważone wysokimi, tereny otwarte za mkniętymi i intensywnymi, obszary kameralne kontrastowane tętriącym tycznym powierzchnie jasne różymi odcieniami cegaty. Zob Norch este $2012 \ldots$ ibidem, s.34

Wynika to ze strategii przeciwdziałania tunelom powietrzyym, występu

hcym w stretach nadmorskich
Na te potrzeby opracowano cztery różne metody interwencij poprzezz
ozbudowe, nadbudowe, super-strukture oraz wypethienie kwartatu no Bezpośrednio pod wiaduktem 2012..., ibidem, 5 as

ment infrastruktury nie był postrzegany wyłaccznie $w$ kategoriach czysto

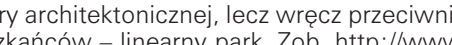
ordhavnen.dk/presse/nyheder/2017/metropladsert+bliver+ nordhavns vitkort aspx (odstona z dnia 0806 18) [17] parks, providing space for the creation of dense and eighbourhood. These two desig tools-density and functional diversity-belong here of of the most important ones in terms of reduct ing the transportation needs.

ENDNOTES 1 The development of this area resulted not only from the con-
stantly changing ship sizes and thus the manners of laading and
unloading cargo, but was also induced by increasing competition from other port centres, primarily Hamburg. See: Nordhavnen
2012. From idea to project, http://www.nordhavnen.dk/english/uk-

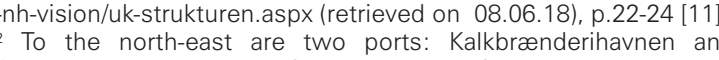
Svanemollehavnen, one of which is used for commercial purpo
ses and the other is a marina. To the north is a container termina and a mixed-use area. The eastern part is the port entrance, which enters deep inland, reaching the heart of Copenhagen. To the sou
ght is the Sondre Frihavn district, also known as the southern port. which is the Sondre Frihavn district, also known as the southern por.
whixture of residential and service functions. Unfortunately, the public reception of these projects in a city
which is so sensitive to matters of sustainable mobility and the ra-

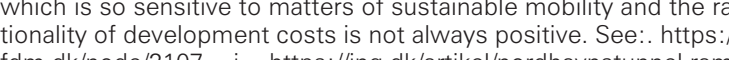
tdm.dk/node/2107 i https://ing.dk/artikel/nordhavnstunnel-ram
mes-af-ekstraregning-paa-100-millioner-kroner-182354 (retrieved mes-af-ekstraregning-paa-100-millioner-kroner-182354 (retrieved
on 08.06.18) [12] [13]. on 08.06 .88 The res
dents dents
5 Nordhavnen $2012 \ldots$, op.cit., p. 4 A Almost all post-industrial areas in Copenhagen located in coastal
areas are currently undergoing transformation into mixed-use ur-
ban complexes/. http://www.nordhavnen.dk/english/uk-nh-vision/uk-nh-compettion.asp (retrieved on 08.06.18) [14]
8The Polyform company

The Polyform company was invited to participate in further design
work on the site development plan in the capacity of an external consultant.
Nordhavnen 2012..., op. cit., p. 10 and http:///urbantransform.eu/ wp-content/uploads/sitiss
trieved on 08.06.18) (15]

Which can be particularly difficult to achieve seeing as-statistientals are practically negligible (see: http:///ec europa eubeurosta statistics explatied/ndex.php?titie=Filie:Distribution of_popul-

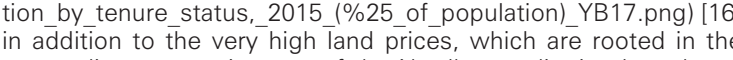
extraordinary attractiveness of the Nordhaven district. In order to
achieve the goal of social diversity in the state budget for 2015 , an amendment to the spatial planning act concerning social housing
was passed. On its basis, local authorities have gained the right to appoint areas of lots on which buildings featuring social housing
are to be built. Buildings built on such lots should feature $25 \%$ heir apartments assigned for public housing, to be rented by less mentent citizens. Another tool assumes the waiver of interest parsocial housing. Thanks to the abovementioned measures, people with lower incomes will be able to live in Nordhaven http://urbangen.pdf $\mathrm{p} .20$ (retrieved on 08.06.18) [15] "Here contrast is understood as balance on various planes of
urban planning. Short buildings are balanced with tall buildings, open areas with closed and densely built-up ones, cameral areas
are contrasted with busy ones, water surfaces are balanced with land, while on aesthetic grounds, bright surfaces are balanced witt
various shades of brick. See: Nordhavnen 2012 . op. cit . 34. It is a result of a strategy of countering air tunnels that appear in seaside zones.
13 Four different intervention methods were developed to answer these needs: extension, upwards extension, super-structure and
filling in an urban block with a new building See:. Nordhavnen 1 There are recreational areas directly underneath the viaduct,
that the infrastructural element is not viewed solely in utilitarian

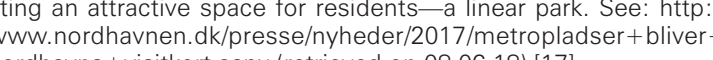
hordhavns + visitkort.aspx (retrieved on 08.06.18) [17]
5 Sustainable mobility is perceived as closer to hum

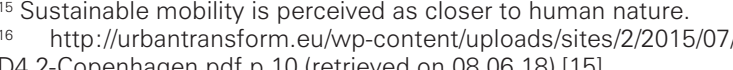
D4.2-Copenhagen.pdf p.10 (retrieved on 08.06.18) [15]
17 Along the longitudinal axis, inside the area, between urban wieka $\underset{16}{{ }_{16}}$ wiek Copenhagen pdt s.10 (ows.eu/wp-content/uploads/sites/2/2015/07/D4 Wzdruz osi podlużej, wewnatrz terenu, pomiędzy kwartatami zabudowy. "Zob. Speck J., Walkable city: how downtown can save America, on ${ }_{2}$ step at a time, Farrar, Straus and Giroux, Nowy York 2012 [18]
20 Zob. Gehl J., Cities for People, Island Press, Waszyngton 2010 [4] 21 Miejscowy plan narzuca obowiązek trzykrotnej zmiany wysokości budynków w obrebie jednej dziatki.
${ }_{22}$ Nordhvnen $2012 \ldots$, ibidem, s.39

${ }_{23}$ Nordhvnen $2012 . .$, ibidem, s.39
http://www.nordhavnen.dk/lenglish/uk-nh-vision/uk-nh-competition

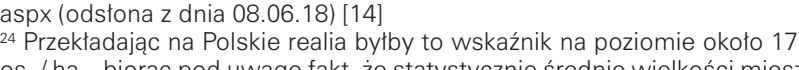
os. / ha - biorac pod uwage fakt, ze statystycznie średnie wielkosci miesz-
kań w Danii sa o o okoto $50 \%$ wiekszen niz w Polsce. Zob. http:l/lec.europa eul/eurostat/statistics-explained/index.php?title = File: Average size
dwelling_by_tenure_status,_2012.png (odstona z dnia 08.06.18) [18]

\section{LITERATURA}

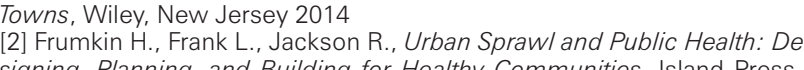
signing, Planning, and Building for Healthy Communities, Island Press.
Waszyngton 2004 [3] Gehl J., Cities for People, Island Press, Waszyngton 2010
[4] Glaeser E. Triumph of the city Pan Macmillan Londyn 5] Jacobs J., Śmierć i życie wielkich miast Ameryki, Fundacja Centrum [6] Jacobs J., The economy of Cities, Vintage Books, New York 1970 (Kin-

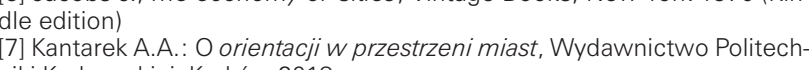
niki Krakowskiej, Kraków 2013 gistance. Creating livable communitites

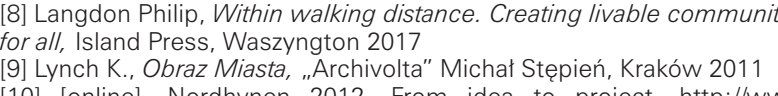

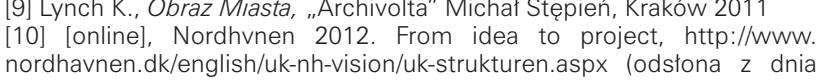

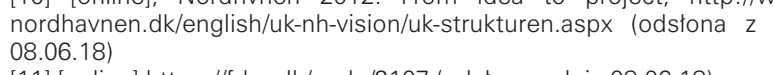

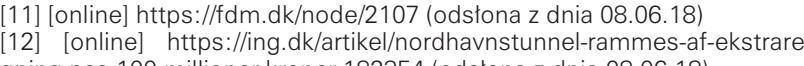
gning-paa-100-millioner-kroner-182354 (odstona z dnia 08.06.18)
[13] [online] http://www nordhavnen.dkkenglish/uk-nh-vision/uk-nh-con petition.asp x xodstona z dnia 08.06.18)

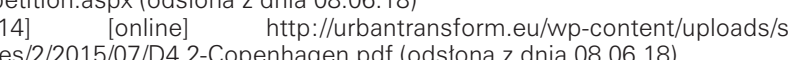

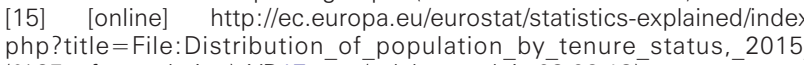

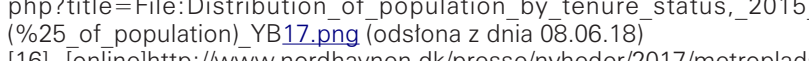
16] [online]http://www.nordhavnen.dk/presse/nyheder/2017

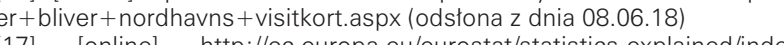
php?title=File:Average_size_of_dwelling_by_tenure_status, 2012.png (10ds] Specck Jnia 08.06.18) Wa kable city: how downtown can save America, one step
10 Nordhavnen 2012..., op. cit., p.61 one step at a time Farrar Straus and Giroux New York 2012 21181

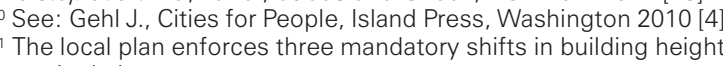
on a single lot.
22 Nordhavnen $2012 \ldots$, op. cit. p. 39

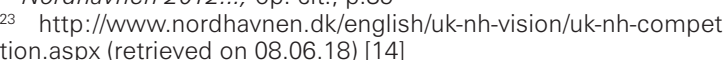

at a level around 171 persons per ha-taking into consideration the fact that, statistically, apartments in Denmark are around $50 \%$ explained/index.php?title=File:Average size of dwelling_by_te

BIBLIOGRAPHY

Ditreet Design: The Secret to Great $C$ 2]
2] Frumkin H., Frank L., Jackson R., Urban Sprawl and Public

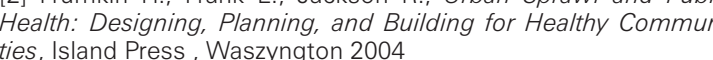
3] Gehl J., Cities for People, Island Press, Waszyngton 2010
44 Glaeser E., Triumph of the city, Pan Macmillan, Londyn 2011 (j) Jacobss J., Smierć i zycie wielkich miast Ameryki, Fundacja Centrum Architektury, Warszawa
$[6]$ Jacobs J., The economy of Cities, Vintage Books, New York 1970 (Kindle edition) B) Langdon Philii Within walking distance. Creating livable communities for all, Island Press, Waszyngton 2017
[9] Lynch K., Obraz Miasta, „Archivolta" Michat Stępień, Kraków

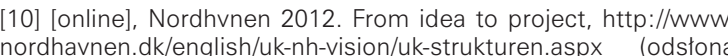

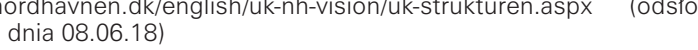
[11] [online] https://fdm.dk/node/2107 (odstona z dnia 08.06.18) [12] [online] https://ing.dk/artikel/nordhavnstunnel-rammes-af-
-ekstraregning-paa-100-millioner-kroner-182354 (odstona z dnia

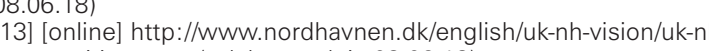
es/2/2015/07/D4.2-Copenhagen.pdf (odstona z z dnia 08.06.18)

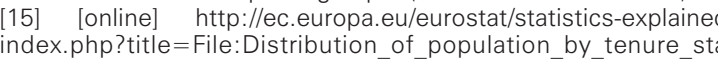

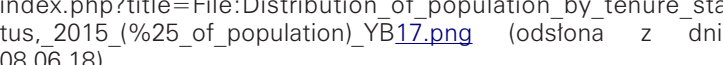

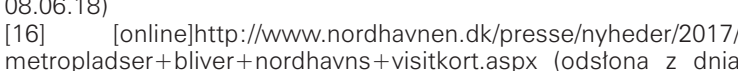
08.06.18)
[17] [online] http:///ec. europa.eu//eurostat/statistics-explained/ index. php? ?title= File: Average size of dwelling_by_tenure_sta-
tus, 2012 . ping (odstonaz dnia 08.06 .18 )

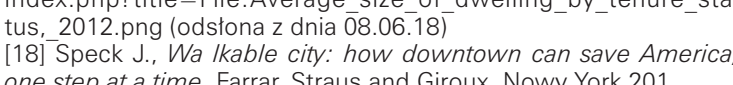

